\title{
Development of Suitable Mitigation Strategy to Counter the Adverse Effect of Heat Stress in Wheat Varieties (Triticum aestivum L.)
}

\author{
Ravi Bhushan Prasad ${ }^{1}$, Monika A. Joshi ${ }^{1}$, Sudipta Basu ${ }^{2}$ and Kiran B. Gaikwad ${ }^{2}$ \\ ${ }^{1}$ Division of Seed Science \& Technology, ICAR- IARI, New Delhi, India \\ ${ }^{2}$ Division of Genetics, ICAR-IARI, New Delhi, India \\ *Corresponding author
}

\begin{tabular}{|l|}
\hline Ke y w or d s \\
Proline content, \\
$\begin{array}{l}\text { Suitable mitigation } \\
\text { strategy, } \\
\text { Tocopherol }\end{array}$ \\
\hline Article Info \\
\hline $\begin{array}{l}\text { Accepted: } \\
\text { 15 December } 2019 \\
\text { Available Online: } \\
\text { 20 January } 2020\end{array}$ \\
\hline
\end{tabular}

\section{Keywords}

Proline content, strategy,

Tocophero

Article Info

Accepted:

Available Online:

\section{A B S T R A C T}

Wheat is a major cereal crop of the world and one third of the world's population uses it as a staple food. However, with the changing climatic scenario and prevalence of higher temperatures, heat stress has become a major factor limiting productivity. Hence, the present study was conducted with the objective to develop suitable mitigation strategy to counter the adverse effect of heat stress. The field experiment was conducted during rabi2017-18 and rabi 2018-19 in the Division of Seed Science and Technology, ICAR Indian Agricultural Research Institute (IARI), New Delhi, India. Seven representative varieties from different zones were used for the present study. The Laboratory studies were conducted in the Division of Seed Science and Technology and Division of Genetics, ICAR-IARI, New Delhi. Heat stress was found to have a significant influence on the seed quality parameters. Germination and vigour Index, I reduced significantly under late sown conditions. Similar trend was observed for VG II. Foliar sprays with different chemicals

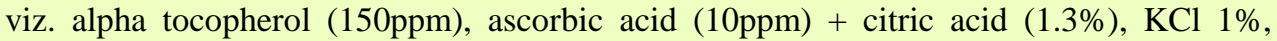
Brassinolides (0.1ppm) and salicylic acid (200ppm) were carried out at vegetative (booting stage) and seed filling stage. Seed harvested from heat stressed environment showed a significant increase in morphological and seed quality parameters when sprayed with various foliar sprays. The result also shows that foliar spray of salicylic acid @ 200ppm and $\mathrm{KCl} 1 \%$ is effective in increasing various morphological parameter like number of seed per spike, thousand seed weight and seed quality parameter of seed. The seed germination and VG I and II were also showing increasing trends. Salicylic acid interacts with proline metabolism and ethylene formation to alleviate the adverse effects of heat stress on photosynthesis in wheat. Application of $\mathrm{KCl}$ results in higher potassium content, increases soluble sugar and proline content in leaf and potentials in maintaining longer green area duration with higher leaf chlorophyll that ultimately contribute to yield and quality of wheat grain and thereby might contribute to heat tolerance. Hence, all foliar sprays could successfully mitigate the effect of heat stress, however, salicylic acid @ $200 \mathrm{ppm}$ and $\mathrm{KCl} 1 \%$ was found to be the most effective. 


\section{Introduction}

Wheat (Triticum aestivum L.) is a major cereal crop of the world and one third of the world's population uses it as a staple food. Wheat production in India during the crop year 2016-17 was 96.68mt (DoAC) with an acreage of $30.37 \mathrm{mha}$.

It is a thermo-sensitive long day crop and is excellent matched to temperate climates; but growing population pressure and increased demand for food has forced farmers to grow wheat in non-traditional, hotter environments where heat stress is major factor limiting wheat productivity. In changing climate scenario, abiotic stresses are serious threat in crop production.

In India, the whole wheat growing area falls under the tropical and subtropical environment. The optimum sowing time for wheat in the major wheat growing area in India (North-west and central India) is first three weeks of November. Wahid et al. 2007 suggested that the best temperature for all physiochemical processes of wheat from vegetative to reproductive stage is $20^{\circ} \mathrm{C}$ or lower.

Wardlaw et al., (1989) reported that the ratio of different protein and carbohydrate is affected due to rise in temperature. Kaur and Behl 2010 reported that a yield reduction of $0.7 \%$ per day occurs when sowing is delayed since the reproductive and ripening phases of growth of late sown wheat crop are generally exposed to high temperature stress during the month of March and April, which in turn reduces the growth and yield. An increase in $1^{\circ} \mathrm{C}$ can decrease grain weight up-to $4 \mathrm{mg}$. Thus, heat stress at different stages of crop, may accelerate the vegetative growth, shorten the phenological events and ultimately reduce the yield. It also has a profound impact on seed quality and seed health status of cereals, mainly because of their impact on nutrient uptake, assimilates supply, partitioning, and remobilization of nutrients.

Exogenous application of certain chemicals elevates the endogenous levels in the heatstressed plants, which are consequently able to maintain significantly greater growth associated with reduction in damage to membranes, cellular oxidizing ability, chlorophyll content, and photochemical efficiency in shoots. In lieu of the above, the present study was carried out to evaluate the effect of foliar sprays on morphological and seed quality parameter and study the micronutrient status of seed.

\section{Materials and Methods}

The experiment was conducted during rabi 2017-18 and 2018-19 in the Division of Seed Science and Technology, ICAR - Indian Agricultural Research institute (IARI), New Delhi, India. Seven representative varieties, from different zones of the country (Table 1) were used for the study.

\section{Timely sown genotypes}

- HD CSW 18: Delhi NCR, timely sown, conservation agriculture

- HD 3171: NEPZ, timely sown, restricted irrigation

- HD 3086: NWPZ, timely sown, irrigated

\section{Late sown genotypes}

- HD 3117: Delhi NCR, late sown, conservation agriculture

- HD 3118: NEPZ, late sown

- HD 3059: NWPZ, late sown

- HD 3090: Peninsular zone, late sown

All the above seven wheat varieties were planted onlate sown condition (in first week 
of January) so that flowering and seed setting takes place under high temperature conditions. Two sprays will be done; first at vegetative and seed filling stage

\section{Results and Discussion}

Effect of foliar sprays on no. of seeds / spike

Seed number per spike ranged from 46.00 to 55.00 in control and 54.00 to 61.0 in sprayed condition, irrespective of genotypes. All foliar sprays are significantly increase no.of seed per spike as compare to control but highest increase is found in T1 (59) followed by T3 (57.50) and T5 (55.17) in timely sown genotypes. Similar trend is found in late sown genotypes. HD show 3171 showed maximum increase in seed number per spike followed by HD CSW 18 (60) and HD 3086 (56) (Table 2). Among the late sown genotypes, HD 3118 showed 54.50 value. Further, HD 3117, showed increase in seed number in comparison to other late sown genotypes.

\section{Effect of foliar sprays on thousand seed weight:}

Thousand seed weight is a critical trait of yield and varies within genotypes. It is result of interaction between genotypes and environment and varies among genotypes and environment. It ranged from 41.00 to $44.50 \mathrm{~g}$ in normal sown genotypes and 39.01-42.50g in late sown genotypes. All foliar sprays are significantly increase thousand seed weight as compare to control but highest increase HD $317144.71 \mathrm{~g}$ recorded highest thousand seed weight followed by HD CSW 18 43.18g and HD $308643.10 \mathrm{~g}$ in timely sown genotypes. Where as in late sown genotypes all foliar sprays are significantly increase thousand seed weight as compare to control and highest increase was found in HD $3059 \quad 42.50 \mathrm{~g}$ followed by HD 3090 41.88g and HD 3117 41.67g (Table 3). So, all the foliar spray was found to be best as compare to control in increasing thousand seed weight in all varieties but highest increase in found in $\mathrm{T} 1$ $(41.73 \mathrm{~g})$ followed by $\mathrm{T} 3(41.32 \mathrm{~g})$ and $\mathrm{T} 5$ (40.90g).

\section{Effect of foliar sprays on seed germination percentage}

Germination percent varied from 85 to $94 \%$ in timely sown cultivar and 84 to $92 \%$ in late sown cultivar. All foliar sprays are significantly increased seed germination as compare to control but highest increase HD $3086(94 \%)$ recorded highest germination \% followed by HD CSW 18 (93\%) and HD $3171(92 \%)$ in timely sown genotypes. Were asin late sown genotypes HD 3059 and HD 3090 (92\%) followed by HD 3117 and HD $3118(90 \%)$ (Table 4).So, all the foliar spray was found to be best as compare to control in increasing germination $\%$ in all varieties but highest increase in found in T1 (93\%) followed by T3 (89 \%) and T5 (86 \%).

\section{Seedling vigour index I}

The VI 1 is a multiple of Germination\% and the seedling length (Root + Shoot) $(\mathrm{cm})$. It is

highly influenced by any abiotic stress experienced by mother plant during seed development and maturation. Vigour index I ranged from 2466. 50 to 3131.50 in timely sown varieties and it ranged from 2226.00 to 3006.50 in late sown genotypes. All foliar sprays are significantly increased vigour index I as compare to control but highest increase HD 3086 (3131.50) recorded highest vigour index I followed by HD 3171 (3042.50) and HD CSW 18 (2931.50) in timely sown genotypes. Where as in late sown genotypes HD 3090 (3006.50) followed by HD 3059 (2925.00) and HD 3117 (2874.50) (Figure 1). So, all the foliar spray was found 
to be best as compare to control in increasing vigour index I in all varieties but highest increase in found in T1 (3035.17) followed by T3 (2865.67) and T5 (2533.00).

\section{Seedling vigour index II}

Vigour index II is a function of seedling dry weight and germination percentage and is a unit less parameter. It is highly influenced by any abiotic stress experienced by mother plant during seed development and maturation. Vigour index II ranged from 40.66 to 58.27in timely sown varieties and it ranged from 36.34 to 49.56 in late sown genotypes. All foliar sprays are significantly increased vigour index II as compare to control but highest

Table.1 Foliar sprays for heat stress mitigation

\begin{tabular}{|c|c|}
\hline Treatment & Concentration \\
\hline T0 & Control \\
\hline T1 & Salicylic acid $(200 \mathrm{ppm})$ \\
\hline T2 & Ascorbic acid (10ppm) + Citric acid \\
\hline & $(1.3 \%)$ \\
\hline T3 & KCL $1 \%$ \\
\hline T4 & Alpha-tocopherol $(150 \mathrm{ppm})$ \\
\hline T5 & Brassinolides $(0.1 \mathrm{ppm})$ \\
\hline
\end{tabular}

Table.1 Effect of foliar sprays on number of seeds per spike

\begin{tabular}{|c|c|c|c|c|c|c|c|}
\hline Variety & T0 & T1 & $\mathbf{T} 2$ & T3 & T4 & T5 & Mean \\
\hline \multicolumn{8}{|c|}{ Timely Sown } \\
\hline $\begin{array}{c}\text { HD CSW } \\
18\end{array}$ & 55.5 & 60 & 56 & 58.5 & 55.5 & 56.5 & 57 \\
\hline HD 3171 & 55.5 & 61 & 56 & 59.5 & 57 & 57 & 57.75 \\
\hline HD 3086 & 51.5 & 56 & 52.5 & 54.5 & 52 & 52.5 & 53.17 \\
\hline Mean & 54.17 & 59 & 54.83 & 57.5 & 55.17 & 55.17 & 55.97 \\
\hline \multicolumn{8}{|c|}{ Late Sown } \\
\hline HD 3117 & 48.5 & 53.5 & 50.5 & 52.5 & 49.5 & 50.5 & 50.67 \\
\hline HD 3118 & 50.5 & 54.5 & 51.5 & 53.5 & 51.5 & 52.5 & 52.33 \\
\hline HD 3059 & 48 & 52 & 50.5 & 50.5 & 48.5 & 49.5 & 49.83 \\
\hline HD 3090 & 46 & 48 & 47 & 47.5 & 46.5 & 47.5 & 47.58 \\
\hline Mean & 50.79 & 55 & 52.43 & 53.79 & 51.93 & 51.79 & \\
\hline Factors & C.D. & & & $\mathrm{SE}(\mathrm{d})$ & & & $\mathrm{SE}(\mathrm{m})$ \\
\hline Factor(A) & 0.808 & & & 0.399 & & & 0.282 \\
\hline Factor(B) & 0.749 & & & 0.369 & & & 0.261 \\
\hline $\begin{array}{c}\text { Factor(A } \\
\text { X B) }\end{array}$ & 1.98 & & & 0.977 & & & 0.691 \\
\hline
\end{tabular}


Int.J.Curr.Microbiol.App.Sci (2020) 9(1): 646-653

Table.2 Effect of foliar sprays on 1000 seed weight (in grams)

\begin{tabular}{|c|c|c|c|c|c|c|c|}
\hline Variety & T0 & T1 & T2 & T3 & T4 & T5 & Mean \\
\hline $\begin{array}{c}\text { HD CSW } \\
\text { 18 }\end{array}$ & 42.4 & 43.18 & 42.35 & 43 & 42.5 & 42.8 & 42.7 \\
\hline HD 3171 & 43.56 & 44.71 & 43.6 & 44.5 & 43.8 & 44 & 44.02 \\
\hline HD 3086 & 41.9 & 43.1 & 41.9 & 42.5 & 42 & 42.2 & 37.26 \\
\hline Mean & 42.62 & 43.66 & 42.61 & 43.33 & 42.76 & 43 & \\
\hline \multicolumn{7}{|c|}{ Late sown } \\
\hline HD 3117 & 40.37 & 41.67 & 40.5 & 41.4 & 40.8 & 41 & 40.95 \\
\hline HD 3118 & 39.01 & 40.88 & 39.5 & 40.5 & 39.4 & 40 & 39.88 \\
\hline HD 3059 & 41.37 & 42.5 & 41.6 & 42 & 41.5 & 41.6 & 41.76 \\
\hline HD 3090 & 40.42 & 41.88 & 40.6 & 41.4 & 40.5 & 41 & 40.96 \\
\hline Mean & 40.29 & 41.73 & 40.55 & 41.32 & 40.55 & 40.9 & \\
\hline Factors & C.D. & & & SE(d) & & & SE(m) \\
\hline Factor(A) & 0.266 & & & 0.131 & & & 0.093 \\
\hline Factor(B) & 0.246 & & & 0.121 & & & 0.086 \\
\hline $\begin{array}{c}\text { Factor (A } \\
\text { X B) }\end{array}$ & 0.65 & & 0.321 & & & 0.227 \\
\hline
\end{tabular}

Table.3 Effect of foliar sprays on seed germination percentage

\begin{tabular}{|c|c|c|c|c|c|c|c|}
\hline Variety & TO & T1 & T2 & T3 & T4 & T5 & Mean \\
\hline \multicolumn{8}{|c|}{ Timely Sown } \\
\hline $\begin{array}{c}\text { HD CSW } \\
18\end{array}$ & 85 & 93 & 87 & 90 & 89 & 87 & 88 \\
\hline HD 3171 & 86 & 92 & 84 & 89 & 88 & 87 & 87 \\
\hline HD 3086 & 88 & 94 & 90 & 90 & 91 & 86 & 90 \\
\hline Mean & 86 & 93 & 87 & 89 & 89 & 86 & 88 \\
\hline \multicolumn{8}{|c|}{ Late Sown } \\
\hline HD 3117 & 85 & 90 & 86 & 89 & 86 & 85 & 86 \\
\hline HD 3118 & 84 & 90 & 85 & 87 & 86 & 86 & 86 \\
\hline HD 3059 & 86 & 92 & 87 & 88 & 89 & 88 & 88 \\
\hline HD 3090 & 85 & 92 & 90 & 92 & 88 & 87 & 89 \\
\hline Mean & 85 & 92 & 87 & 89 & 88 & 86 & \\
\hline Factors & C.D. & & & $\mathrm{SE}(\mathrm{d})$ & & & $\mathrm{SE}(\mathrm{m})$ \\
\hline Factor(A) & 0.98 & & & 0.484 & & & 0.342 \\
\hline Factor(B) & 0.907 & & & 0.448 & & & 0.317 \\
\hline $\begin{array}{c}\text { Factor (A X } \\
\text { B) }\end{array}$ & 2.4 & & & 1.185 & & & 0.838 \\
\hline
\end{tabular}


Figure.1 Effect of foliar sprays on seedling vigour Index I

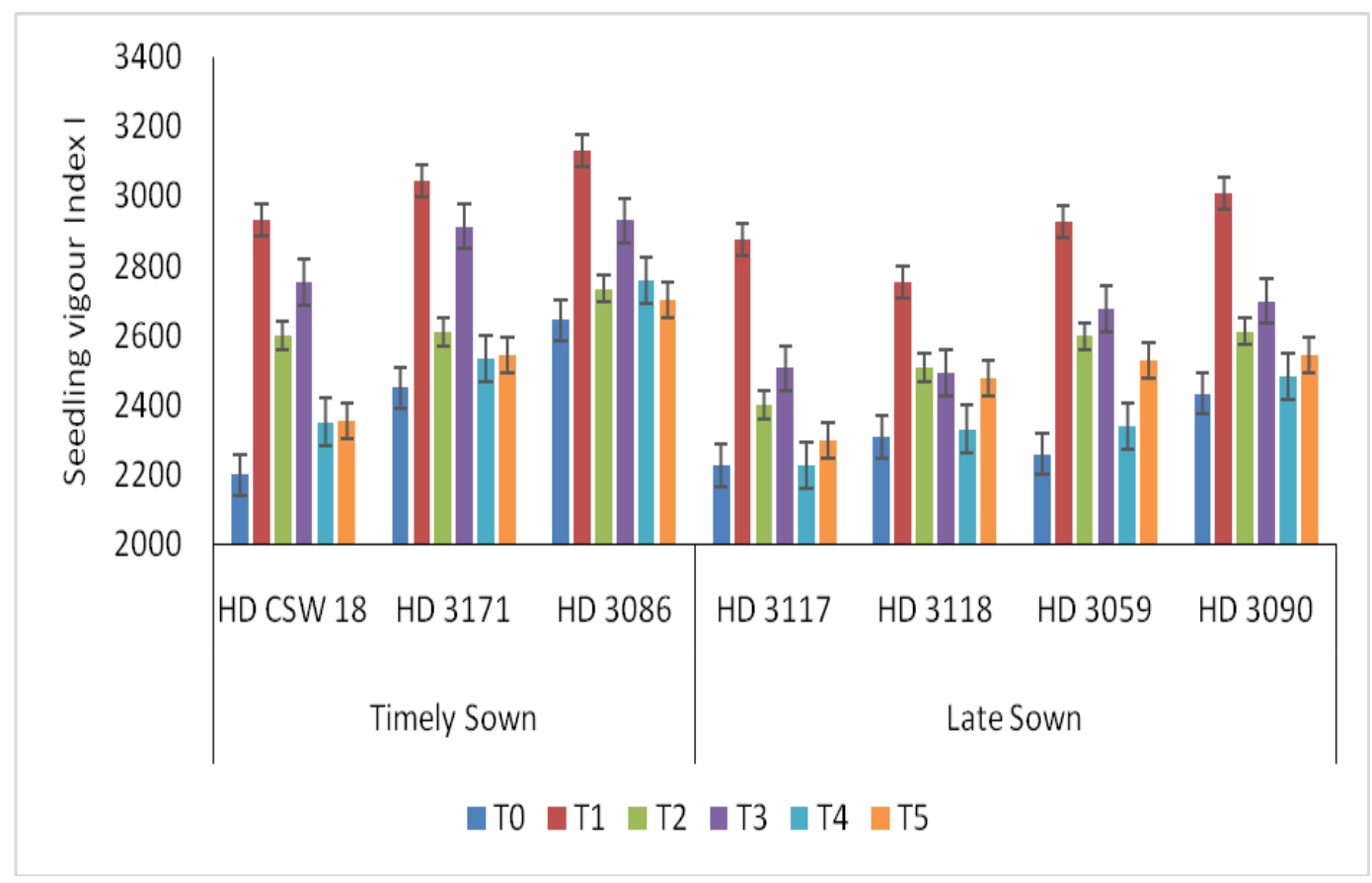

Figure.2 Effect of foliar sprays on seedling vigour Index II

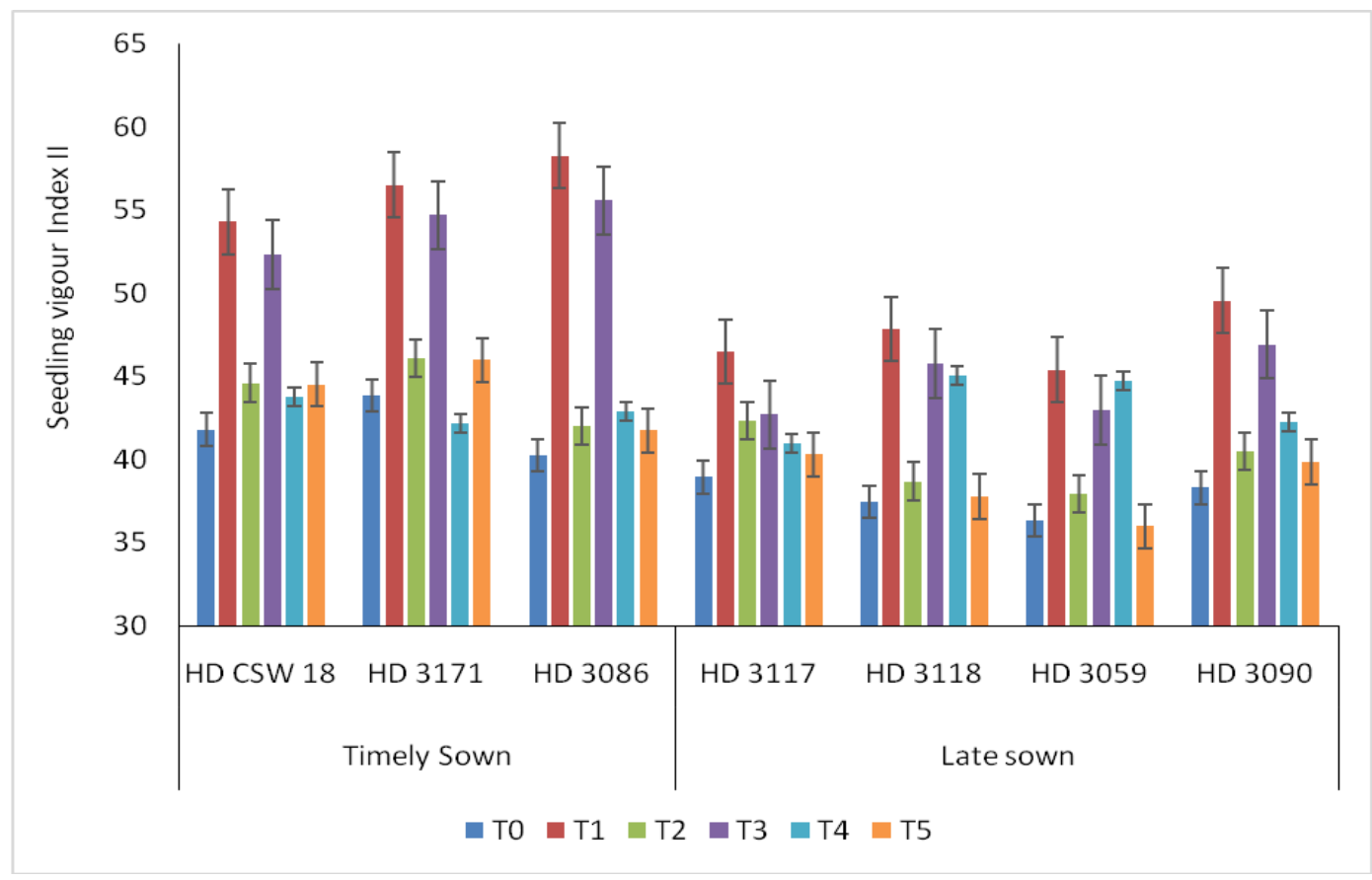

increase HD 3086 (58.27) recorded highest vigour index I followed by HD 3171 (56.51) and HD CSW 18 (54.59) in timely sown genotypes.Were asin late sown genotypes HD
3090 (49.56) followed by HD 3118 (47.84) and HD 3117 (46.50) (Figure 2). So, all the foliar spray was found to be best as compare to control in increasing vigour index $\mathrm{I}$ in all 
varieties but highest increase in found in $\mathrm{T} 1$ (56.35) followed by T3 (54.20) and T5 (44.07).

Seadh and El-Metwally, 2015; Kazemi, 2013 and Khan et al.,2013 reported similar results in the efficacy of salicylic acid in heat stress mitigation and suggested that SA interacts with proline metabolism and ethylene formation to alleviate the adverse effects of heat stress on photosynthesis in wheat. Episodes of heat stress around anthesis severely reduce the final number of grains per spike due to an increased abortion of ovules (Pradhan et al., 2012; Weldearegay et al., 2012). Seed number per spike ranged from 46.00 to 55.00 in control and 54.00 to 61.0 in sprayed condition, irrespective of genotypes. All foliar sprays are significantly increase number of seed per spike as compare to control but highest increase is found in T1 (59) followed by T3 (57.50) and T5 (55.17) in timely sown genotypes. These results were similar to those of Haq and Khan (2002) and Shah and Akmal (2002). Joshi et al., (2016) and Hossain et al., (2012 a, 2012b), reported a subsequent decrease in 1000-seed weight in wheat with delayed sowing. It ranged from 41.00 to $44.50 \mathrm{~g}$ in normal sown genotypes and 39.01-42.50g in late sown genotypes. All foliar sprays are significantly increase thousand seed weight as compare to control but highest increase HD $3171 \quad 44.71 \mathrm{~g}$ recorded highest thousand seed weight followed by HD CSW 18 43.18g. Similar results was also found byKumar et al., (2013), that spraying with salicylic acid increase the thousand grain weight of seed as compare to control. All foliar sprays are significantly increased seed germination percentage, seedling vigor index I and II as compare to control. Similar results were also reported by Soltani et al., (2012). These results suggest that SA increase the all morphological and seed quality parameter under stress conditions. It is concluded that the study reveales the heat stress affect seed quality parameter. The exogenous foliar application significantly increases all morphological and seed quality parameter as compare to control.

\section{References}

Haq, N. U. and Khan, M. (2002). Effect of planting date, chlortoluran + MCPA and wheat varieties on weed control and wheat yield. Sarhad J. Agric. 18: 443447.

Hossain, A, Lozovskaya, M.V., Zvolinsky, VP, TeixeiradaSilva J.A. (2012b). Effect of soil and climate conditions on yield-related components performance of spring wheat (Triticum aestivum L.) varieties in the northern Bangladesh. Natural Sciences: J. Fund. Appl. Sci. 39(2): 69-78.

Hossain, A, Lozovskaya, MV, Zvolinsky VP, Teixeirada Silva JA (2012a) Effect of soil and climatic conditions on phenology of spring wheat varieties in the northern Bangladesh. Natural Sciences: J. of Fund. Appl. Sci. 39(2): 78-86.

Joshi, M. A., Sahzad, F. and Kumar, A. (2016). Effect of heat stress on crop phenology, yield and seed quality attributes of wheat (Triticum aestivum L.). J. Agrometeorology, 18(2): 206215.

Kaur, V., and Behl, R. (2010).Grain yield in wheat as affected by short periods of high temperature, drought and their interaction during pre-and post-anthesis stages. Cereal Research Communications, 38(4): 514-520.

Kazemi, M. (2013). Foliar application of salicylic acid and calcium on yield, 
yield component and chemical properties of strawberry. Bull. Env. Pharmacol. Life Sci, 2(11): 19-23.

Khan, M. I. R., Iqbal, N., Masood, A., Per, T. S., and Khan, N. A. (2013). Salicylic acid alleviates adverse effects of heat stress on photosynthesis through changes in proline production and ethylene formation. Plant signalling and behavior, 8(11): 263-278.

Kumar, S., Singh, R., and Nayyar, $H$. (2013). $\alpha$-Tocopherol application modulates the response of wheat (Triticum aestivum L.) seedlings to elevated temperatures by mitigation of stress injury and enhancement of antioxidants. Journal of plant growth regulation, 32(2): 307-314.

Pradhan, G.P., Prasad, P.V.V., Fritz, A.K., Kirkham, M.B., Gill, B.S. (2012). Effects of drought and high temperature stress on synthetic hexaploid wheat. Functional Pl. Bio. 39: 190-198.

Seadh, S. E., and El-Metwally, M. A. (2015). Influence of antioxidants on wheat productivity, quality and seed-borne fungi management under NPK fertilization levels. Asian Journal of Crop Science, 7(2): 87.
Shah, M.S.S. and Akmal, M. (2002). Effect of different sowing dates on yield and yield components of wheat varieties. Sarhad J. Agric.18: 143-149.

Soltani, Y., Saffari, V. R., Moud, A. A. M., and Mehrabani, M. (2012). Effect of foliar application of $\alpha$-tocopherol and pyridoxine on vegetative growth, flowering, and some biochemical constituents of Calendula officinalis L. plants. African Journal of Biotechnology, 11(56): 11931-11935.

Wahid, A., Gelani, S., Ashraf, M., and Foolad, M. R. (2007). Heat tolerance in plants: an overview. Environmental and experimental botany, 61(3): 199-223.

Wardlaw, I. F., Dawson, I. A., and Munibi, P. (1989). The tolerance of wheat to high temperatures during reproductive growth. 2. Grain development. Crop and Pasture Science, 40(1): 15-24.

Weldearegay, D.F., Yan, F., Jiang, D., Liu, F. (2012). Independent and combined effects of soil warming and drought stress during anthesis on seed set and grain yield in two spring wheat varieties. J. Argo. Crop Sci. 198: 245253.

\section{How to cite this article:}

Ravi Bhushan Prasad, Monika A. Joshi, Sudipta Basu and Kiran B. Gaikwad. 2020. Development of Suitable Mitigation Strategy to Counter The Adverse Effect of Heat Stress in Wheat Varieties (Triticum aestivum L.). Int.J.Curr.Microbiol.App.Sci. 9(01): 646-653. doi: https://doi.org/10.20546/ijcmas.2020.901.070 